\title{
A Middle Palaeolithic burial of a modern human at Taramsa Hill, Egypt
}

\author{
P.M. Vermeersch, E. Paulissen, S. Stokes, C. Charlier, \\ P. VAN PeER, C. STRINGer \& W. LindSAY ${ }^{\star}$
}

\begin{abstract}
Discussion about a possible African origin of modern humans is hampered by the lack of Late Pleistocene skeletal material from the Nile valley, the likely passage-way from East Africa to Asia and Europe. Here we report the discovery of a burial of an anatomically modern child from southern Egypt. Its clear relation with Middle Palaeolithic chert extraction activities and a series of OSL dates, from correlative aeolian sands, suggests an age between 49,800 and 80,400 years ago, with a mean age of 55,000.
\end{abstract}

Key-words: Egypt, early modern buman, Middle Palaeolithic, burial

\section{Excavation}

Taramsa Hill, near Qena in Upper Egypt, is an isolated landform, situated some $2.5 \mathrm{~km}$ southeast of the Dandara temple $\left(26^{\circ} 6^{\prime} \mathrm{N} 32^{\circ} 42^{\prime} \mathrm{E}\right)$ (FIGURE 1). The hill is capped with a 4-m thick cobble deposit. Excavations have been carried out at the site, called Taramsa 1, since 1989 (Vermeersch et al. 1995).

The site was used for systematic quarrying of chert cobbles, as demonstrated by numerous pits and trenches. On the basis of both typology and stratigraphy, multiple quarrying phases fall into three main extraction periods, of early, mid and late Middle Palaeolithic respectively (Vermeersch in press). The early Middle Palaeolithic is characterized by the presence of handaxes, foliates and Nubian point and flake Levallois methods. In stratigraphically superimposed assemblages, assigned to the mid Middle Palaeolithic, foliates and handaxes are lacking but the Nubian point and flake Levallois methods continue to be represented. The latest assemblages, established through stratigraphical observations, do not contain Nubian point Levallois methods but they are characterized by a Levallois reduction system that is transitional to the systematic production of blades. In these late Middle Palaeolithic assemblages we are confronted with a changing Levallois production, not unlike the transitional assemblages known in the Negev (Marks 1976-83).

During a visit to the site, while surveying the Taramsa area for other extraction sites in March 1994, a heavily weathered skull was discovered in a collapsing ancient trench section (FIGURE 2). We decided to excavate the find immediately in order to prevent it from being destroyed further. During the excavation, other skeletal components in their anatomical position were discovered (FIGURE 3).

The skeleton (apparently a child) was poorly preserved and very fragile, and we decided to consolidate the sediments round it. In this way we were able to preserve the skull, which is now embedded in consolidated sands. The clavicle, scapula and the vertebral column were so completely weathered that they could not be recovered. Some traces of ribs could be observed

* Vermeersch, Paulissen \& Van Peer, Instituut voor Aardwetenschappen, Katholieke Universiteit Leuven,

Redingenstraat 16, B-3000 Leuven, Belgium. pierre.vermeersch@geo.kuleuven.ac.be

Stokes, School of Geography, Research Laboratory for Archaeology \& the History of Art, Oxford University, 6 Keble Road, Oxford ox1 30, England.

Charlier, Centre for Human Genetics, Katholieke Universiteit Leuven, Herestraat 49, B-3000 Leuven, Belgium, and Anthropologisches Insitut der Universität Kiel, Olsenhausenstraße 40-60, D-24118 Kiel, Germany.

Stringer \& Lindsay, Department of Palaeontology, Natural History Museum, Cromwell Road, London Sw7 5BD, England.

Received 4 September 1997, accepted 30 January 1998, revised 28 February 1998.

ANTIQUITY 72 (1998): $475-84$ 


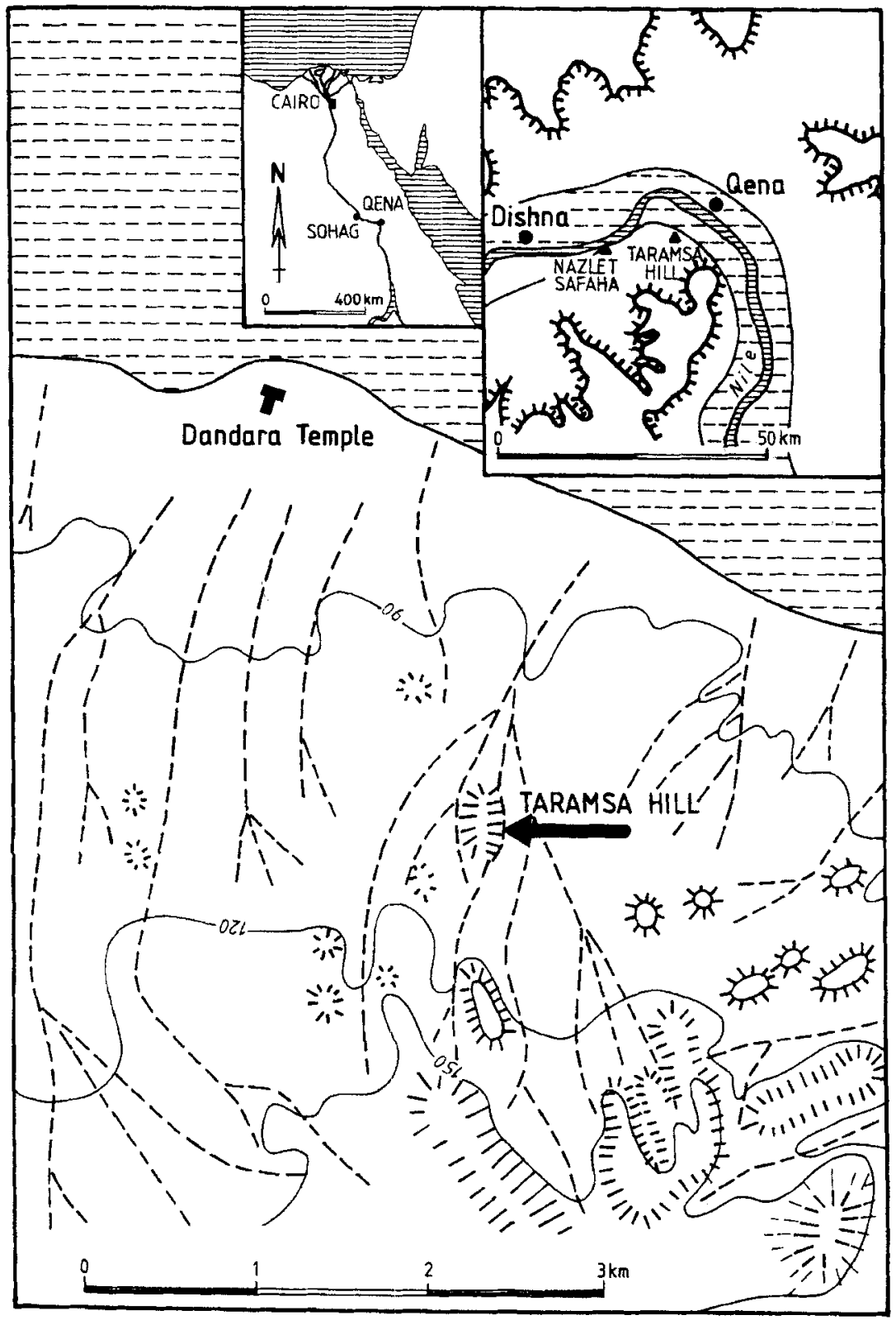

FIGURE 1. Site plan.

in the chest region but they were unrecoverable. No bones from the pelvis, or from its hands or feet, were found. Only the shafts of the long bones were more or less preserved. Even after a careful conservation attempt, most bone shafts collapsed during recovery. The skeleton was leaning backwards in a seated position, oriented towards the east, with the head oriented skywards, resting upon a sand bed containing fewer cobbles. The legs were bent to the left in a pro- nounced contracted position. The left arm was also bent, resting upon the pelvis. The right arm was stretched down behind the back of the skeleton.

During the excavation full attention has been paid to all observations that could exclude or confirm the possibility that the burial was an intrusion into older deposits. All our observations point firmly to the conclusion that the skeleton is contemporaneous with the surround- 


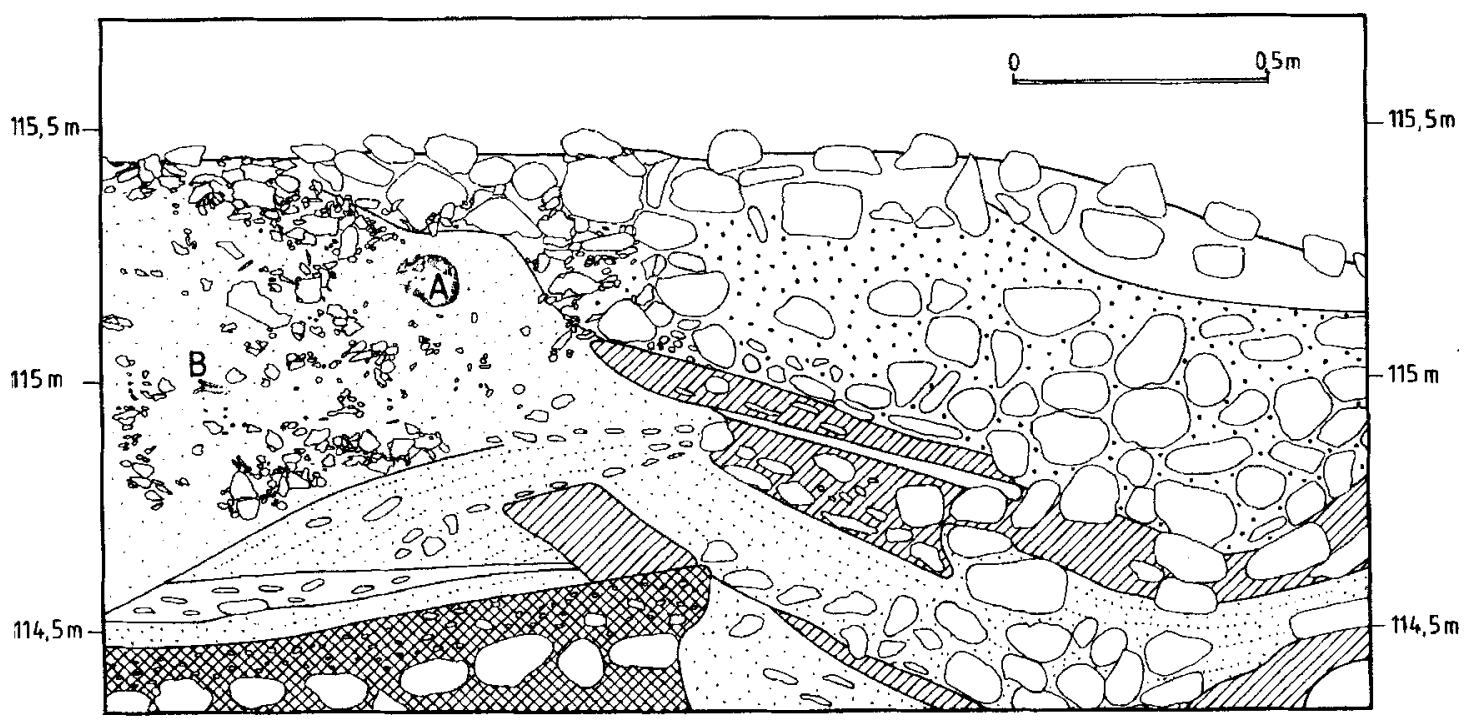

FIGURE 2. Section with the burial. $\mathrm{A}=$ the skull; $\mathrm{B}=$ a tibia; the deposit with the burial is fully covered by Middle Palaeolithic extraction dump, itself overlying older extraction dump; hatched area = red dump deposits; crosshatched = terrace deposits with raw material in situ.

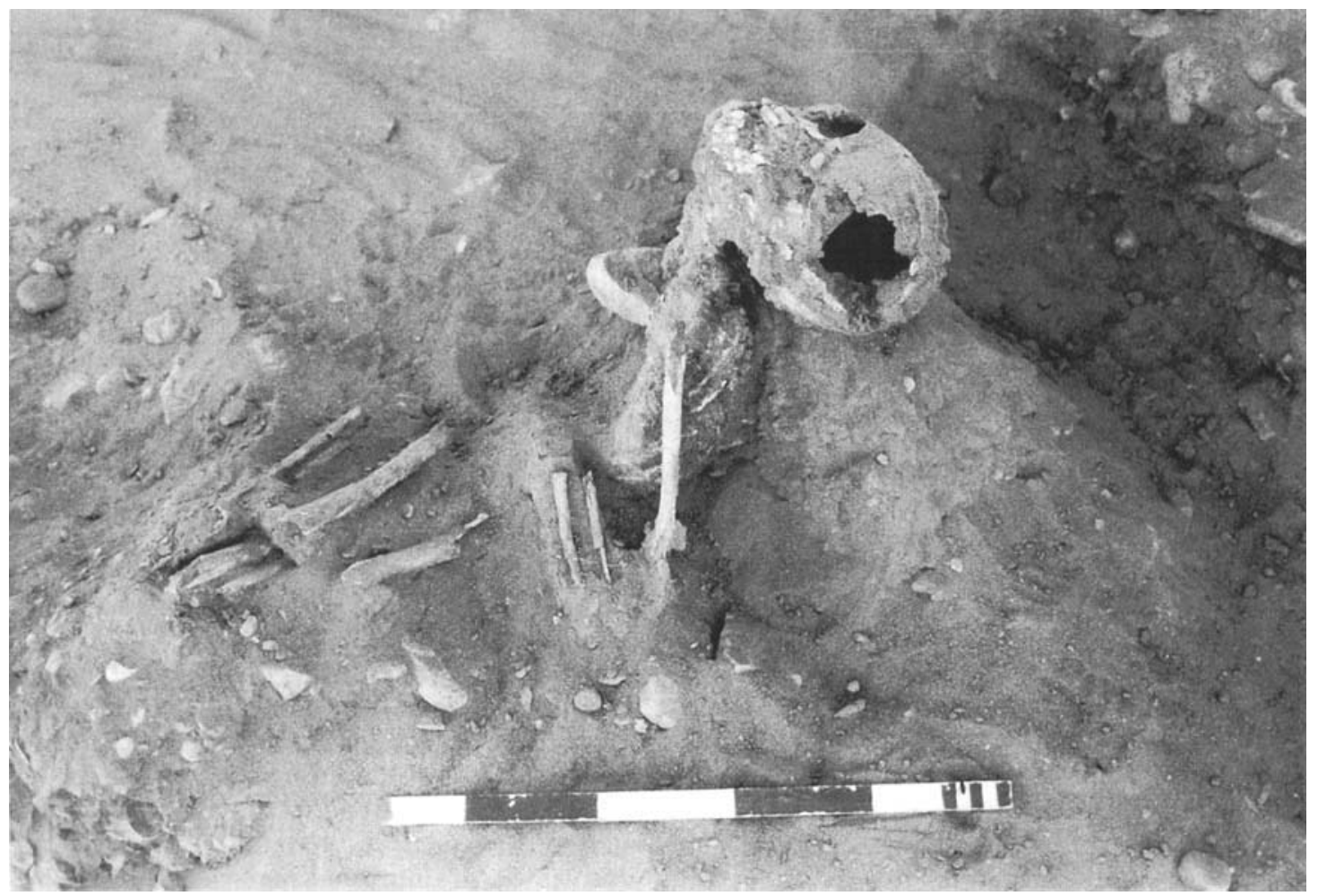

FIGURE 3. The skeleton after excavation.

ing deposits. The corpse was deposited against the southwestern side of a prehistoric extrac- tion pit which was $5 \mathrm{~m}$ long, $4 \mathrm{~m}$ wide and had a maximum depth of $1.2 \mathrm{~m}$ (FIGURE 4 ), the 


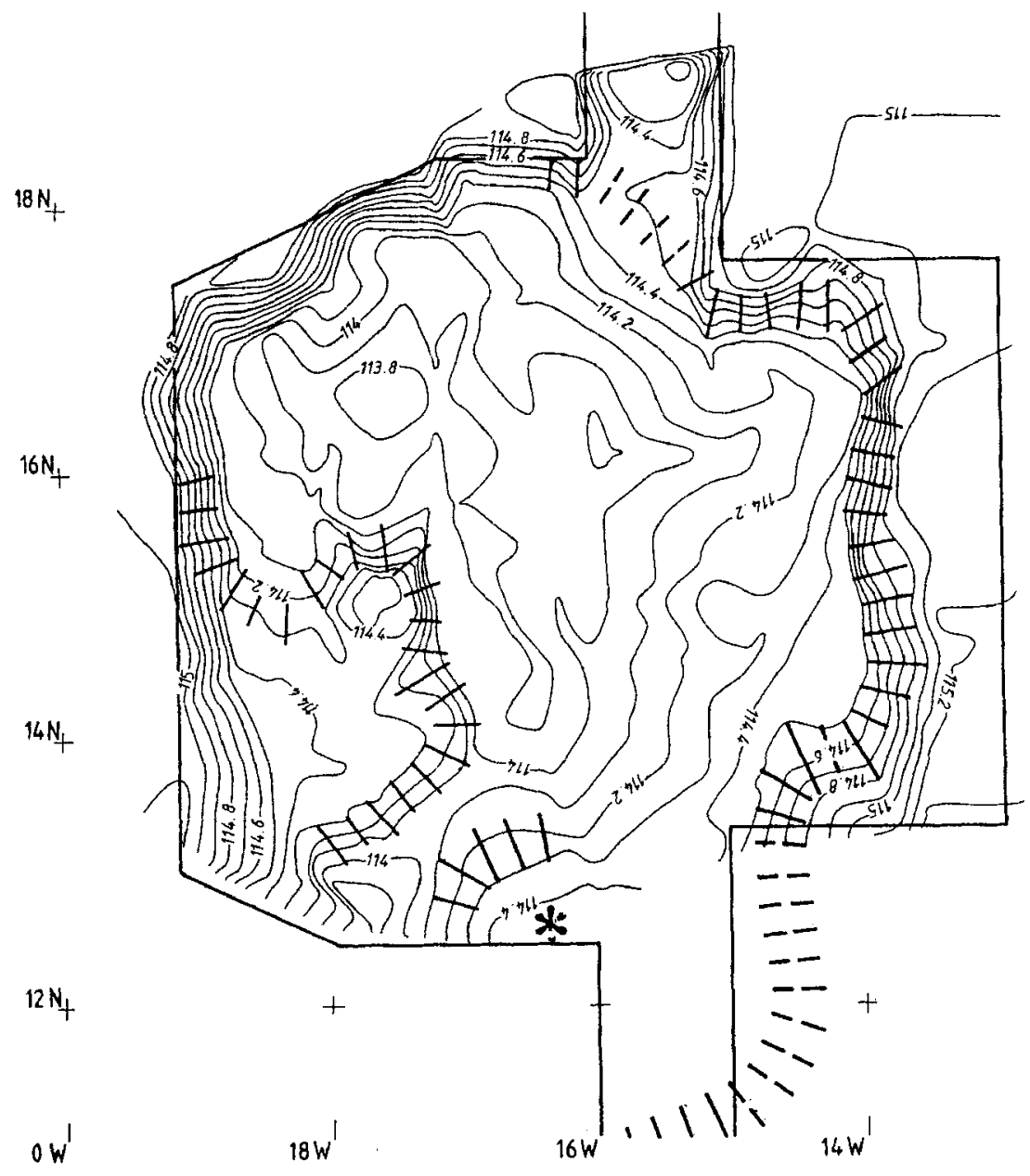

FIGURE 4. Topography of the extraction pit with the position of the burial indicated by asterisk. main part of which was excavated by us during the 1991 campaign. It was clear that the extraction occurred over at least two different phases. The first was organized by humans from the mid Middle Palaeolithic, where cobbles were extracted from the terrace deposits. During a second exploitation phase, the mid Middle Palaeolithic dump, together with fresh cobbles, was re-exploited by late Middle Palaeolithic humans. This interpretation is based on the clear sequence of dumps above the in situ terrace cobbles: the lowest one containing only mid Middle Palaeolithic artefacts and the upper one containing a mixture of mid Middle Palaeolithic and late Middle Palaeolithic artefacts.

\section{Context}

The skeleton (discovered in square $12 \mathrm{~N} 16 \mathrm{~W}$ ) (FIGURE 4) was sitting on a 10 -cm layer of ex- traction debris, leaning against the unexploited terrace cobbles. It was surrounded by extraction dump deposits of gravelly sand, mixed with numerous artefacts, Nubian and classical Levallois cores, single platform cores, Levallois flakes and large numbers of blades, flakes and chips, all characteristic of the mid Middle and late Middle Palaeolithic (FIGURE 5). There are, however, no arguments to consider them grave goods associated with the burial.

From the seated position of the skeleton and its dump environment, an intentional burial can be assumed. The body was simply laid down against the side of the extraction pit and covered up by the dumped material. Because of its shallow position, deposited at a depth of no more than $1 \mathrm{~m}$ below surface, we exclude the possibility that the person had died by accident due to the collapse of the pit walls. 


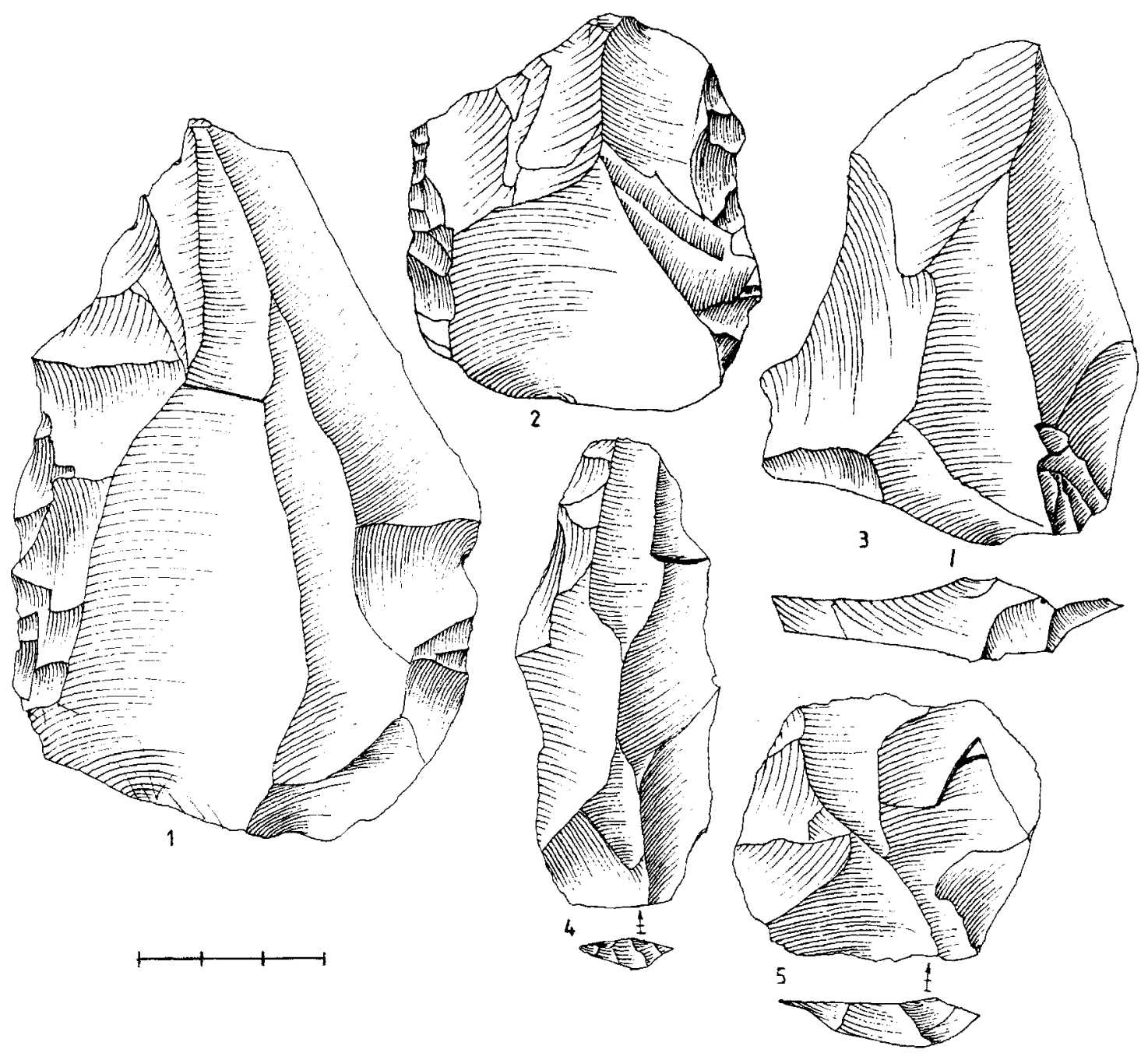

FIGURE 5. Artefacts from the dump surrounding the skeleton.

Mid Middle Palaeolithic: $1,2=$ Nubian point core; $3=$ Nubian point $5=$ Levallois flake. Late Middle Palaeolithic: 4 = blade.

A Pleistocene age for the burial can be deduced because the skeleton was sealed by an aridisol that had formed during the more humid phase of the Holocene (from 9500 up to 6000 years ago in this area). This aridisol uniformly follows the actual surface, affecting in a similar way the surface above and around the burial.

The decisive argument for the burial occurring during the late Middle Palaeolithic extraction activities is the observation that the skeleton was sealed by an undisturbed layer of extracted cobbles, which dips towards the undisturbed terrace deposits on the west (FIGURE 2).
Stratigraphically, this cobble layer is covered by dump deposits of another Middle Palaeolithic extraction pit. Moreover, no extraction activities from a period later than the late Middle Palaeolithic have been discovered at Taramsa Hill during our very extensive excavations. The presence of late Middle Palaeolithic artefacts, associated with a majority of mid Middle Palaeolithic ones, in the deposits surrounding the skeleton, suggests an association with the late Middle Palaeolithic.

The skeleton is currently stored in Egypt, whilst a request for study loan of the skeleton has been under consideration since 1994. Un- 
fortunately, due to administrative problems, no permit to export the skeleton has yet been granted. We fear that the very fragile bones will suffer a great deal from not being treated and consolidated in an adequate way.

Although the skeleton requires much more research, we consider it a necessity to let the scientific community know of this very early African burial.

\section{OSL dating}

In an attempt to date the extraction activities at Taramsa 1, one of us (SS) has used optical dating (Huntley et al. 1985; Smith et al. 1986) on the aeolian sands. Details of the technique and its application to Middle Palaeolithic chert mining sites in the Nile Valley will be discussed in a forthcoming article. The key factors which make the techniques applicable relate both to the aeolian nature of the infill materials and the inferred rapid (effectively instantaneous) infilling of the excavation trenches. The method has demonstrated its ability to date the last Interglacial and more recent periods in close agreement with high precision uranium series and amino acid racemization age estimates in arid areas in the adjacent Western Desert (Stokes 1993).

Samples of the aeolian infill were collected for optical dating. This material covers the extraction pits and the dump containing numerous artefact concentrations and thus provides a terminus ante quem for the artefacts sealed beneath it. Furthermore, the pits were used for knapping when already partly filled by dumped material and aeolian sand, and the aeolian infill

\section{dose $T$ sample}

ass

association palaeo- error dose

(A) (A)

$897 \_10$
$793 \_1$
$897 \_11$
$897 \_10 \mathrm{C}$
$793 \_2$
$793 \_3$
$897 \_1$
$897 \_2$
$897 \_8$

$\begin{array}{lrr}\text { above LMP } & 62 & \pm 13 \\ \text { above LMP } & 78 & \pm 16 \\ \text { above LMP } & 72 & \pm 20 \\ \text { above LMP } & 62 & \pm 13 \\ \text { above LMP } & 88 & \pm 19 \\ \text { above LMP } & 96 & \pm 21 \\ \text { below LMP } & 169 & \pm 74 \\ \text { above LMP } & 99 & \pm 26 \\ \text { above LMP } & 97 & \pm 23\end{array}$

palaeo- error
dose (B)

(B) is clearly contemporaneous with the extraction activity, with knapping debris incorporated into it.

The samples (see TABLE 1) were collected from different late Middle Palaeolithic (LMP) extraction pits at Taramsa 1 . The dates (not published here), obtained from the mid Middle Palaeolithic extraction pits, are older, and no younger extraction pits have been found. The determinations we present here are the results of samples where the association between dated aeolian sands and the Late Middle Palaeolithic material is based on stratigraphical evidence showing that the aeolian sand below and above the artefact concentrations in the extraction pits are of the same time period.

The optical dating was carried out on 90$150-\mu \mathrm{m}$ quartz grains extracted from the sediment samples and environmental dosimetry was undertaken via a combination of in situ and laboratory-based methods (TABLE 1). Samples for optical dating were collected by hammering $500 \mathrm{~cm}^{3}$ light-proof PVC cylinders horizontally into the vertical walls of freshly cleaned exposures. All samples were processed under subdued red light. Each was wet-sieved (retaining 90-150- $\mu \mathrm{m}$ size fraction) and immersed for two days in $1 \mathrm{~N} \mathrm{HCl}$, followed by a two-day immersion in $\mathrm{H}_{2} \mathrm{O}_{2}$. Heavy minerals $(\rho>2.72 \mathrm{~g}$ $\mathrm{cm}^{-3}$ ) were separated by magnetic and heavy liquid (sodium polytungstate) methods, the remaining light minerals etched with $48 \% \mathrm{HF}$ (60 minutes) and $35 \% \mathrm{H}_{2} \mathrm{SiF}_{6}$ (4 days), and resieved at $75 \mu \mathrm{m}$. The quartz separates were mounted as monolayers (c. $5 \mathrm{mg}$ per disc) on to $10-\mathrm{mm}$ diameter stainless steel discs using

TABLE 1. OSL dating results on aeolian sands, filling pits exploited during the Late Middle Palaeolithic from Taramsa 1. 
silicone spray adhesive. Palaeodoses were calculated using the multiple aliquot additive dose method (Aitken 1985). Aliquots were exposed to an argon laser (Coherent $2 \mathrm{~W}, \lambda=514.5 \mathrm{~nm}$, power at sample $\left.=c .40 \mathrm{~mW} \cdot \mathrm{cm}^{-2}\right)$, OSL emissions detected using a Philips 9635Q PMT filtered by BG-39 and Corning 7-51 glass filters. Two separate analyses were undertaken using both $220^{\circ} \mathrm{C}$ ( 5 minutes) and $160^{\circ} \mathrm{C}$ (16 hours) pre-heat procedures. Final palaeodose estimates are based on the naturally normalized (Stokes 1994) optically-stimulated luminescence (OSL) emission from a $3 \mathrm{~J} . \mathrm{cm}^{-2}$ laser exposure and are weighted averages of the two independent analyses. Sample splits for dose rate determinations were crushed and homogenized by ring milling for 1 hour. $\mathrm{K}, \mathrm{U}$ and Th concentrations for samples 793/1-3 were estimated via thick source alpha counting and flame photometry (Stokes 1994). The isotopes of interest for all other samples were measured using neutron activation analysis and field gamma spectrometry. These estimates were converted to the beta and gamma dose rates respectively. Saturation moisture content (W) was estimated at 0.4 , and the estimated average moisture content over the burial period $(\mathrm{F})$ as 0.125 . The cosmic ray dose rate contribution was estimated via in situ gamma ray spectrometry. The calculated dates incorporate random and systematic errors (Aitken 1985), and are quoted to \pm 1 standard deviation.

The late Middle Palaeolithic, to which the burial and the skeleton are associated, has provided several OSL dates ( $c f$. TABLE 1), ranging from 49.8 up to $80.4 \mathrm{ka}$ BP. A weighted average of all available dates for this extraction period gives a date of $55 \cdot 5 \pm 3 \cdot 7 \mathrm{ka} \mathrm{BP}$. In the absence of a date on the skeleton itself, we accept this date as the best current estimation for the age of the skeleton.

\section{Anthropological observations}

A first attempt to determine the individual's age at death, as well as a rough approximation of the systematic position of the individual within the known North African and Levantine fossil records has been proposed by one of us (CC) based only on the photographic documentation from 1994. The teeth are quite large and seem to be aligned in four rows in the jaws (FIGURE 6). On the photographs, the dental area occupies an important part of the total projected surface of the head. By comparison, the braincase looks gracile. This contrast is strongly reminiscent of the young adult female Qafzeh 9 (Vandermeersch 1981).

The buccal surface of the crowns is strongly convex. This is especially true for the huge upper permanent canine, the deciduous canines and premolars, less so for the permanent lower incisors. The first upper permanent molar $\left(\mathrm{M}^{1}\right)$ and the second upper deciduous premolar $\left(\mathrm{p}^{2}\right)$ show a transverse bulging at the base of their crowns (buccal surface), which is reminiscent of a cingulum (FIGURE 6). The dentition could indicate an age range of 8-10 years by present standards (TABLE 2; Brothwell 1972; Legoux 1966; Smith 1991; Ubelaker 1978). The apparent ${ }^{1}$ absolute dimensions of the teeth would place the child of Taramsa close to the human remains from Témara, Dar-es-Soltan, Mugharat el-Aliya and Jebel Irhoud (Vallois \& Roche 1958; Vallois 1951; Ennouchi 1962a; 1962b; Hublin \& Tillier 1981). The 'small-toothed' Upper and Epipalaeolithic people from Afalou, Taforalt, Nazlet Khater, Gebel Sahaba, Wadi Halfa and the European Upper Palaeolithic would cluster apart, as a distinct group (Arambourg et al. 1934; Ferembach 1962; Thoma 1984; Anderson 1968; Greene \& Armelagos 1972; Hublin \& Tillier 1981). The early modern humans from the Levant show much variability in respect of tooth dimensions (McCown \& Keith 1939; Vandermeersch 1981; Hublin \& Tillier 1981; Tillier 1979; 1984).

Although the skeleton is very fragile, and the mandible has almost totally disappeared, teeth and tooth fragments remain in position, mixed with sand, and still retain the original shape of the jaw: it seems to be parabolic.

The skeleton appears to belong to an anatomically modern child. This is particularly evident from the morphology of the frontal bone which shows none of the recession or supraorbital development which would be expected in immature archaic humans at this developmental stage. Many features seem to be close to those of the robust Epipalaeolithic populations of North-Africa ('Mechtoids') but also to those of the early anatomically modern humans of the Levant. The slenderness of the long bones, the rounding of the forehead and of the

1 The teeth have not been measured; this estimation rests on their aspect on the photographic documentation. 


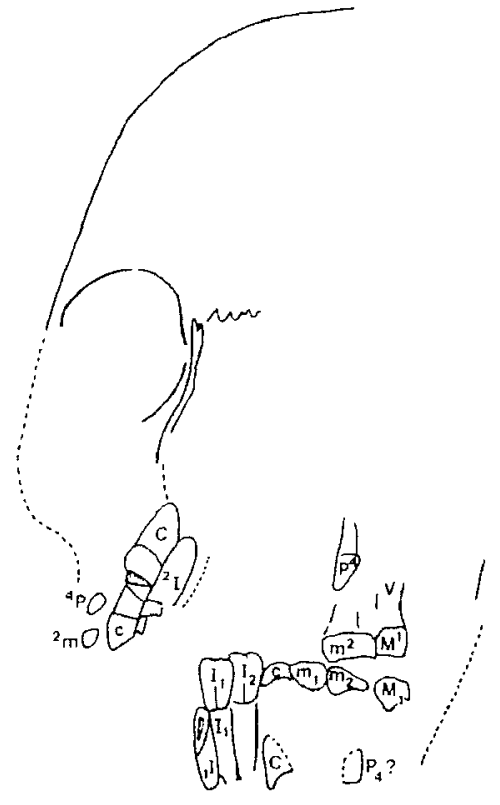

FIGURE 6. The skull with a graph showing the position of the teeth.

occipital region, the pentagonoid shape of the skull in occipital view and certain details of the orbits and their surroundings are undoubtedly anatomically modern features. On the other hand, the relatively large and apparently prognathic face may set this child closer to the more primitive forms of Jebel Irhoud, rather than the above-mentioned Mechtoid populations. Further comparisons with subsaharan Africa are necessary. On the basis of this preliminary assessment, an attempt to place this skeleton in a precise phylogenetic position would be dangerous. The fact that the skeleton belongs to a child who had not yet developed all the characteristics of an adult individual invites caution. Fur-

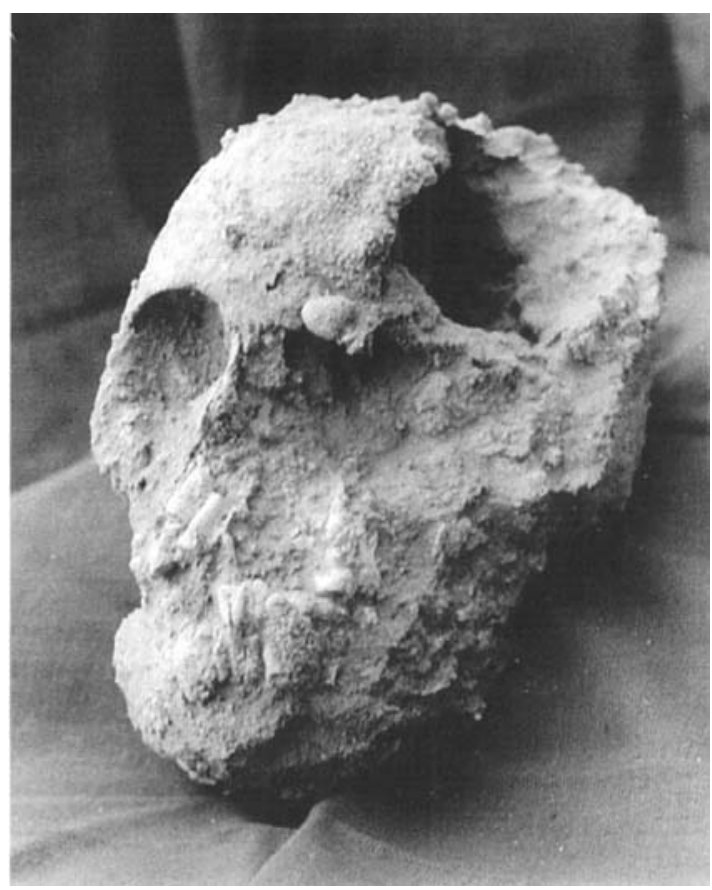

ther study will be carried out on the surviving fragments after conservation and preparation.

The most striking feature of the post-cranial skeleton - also recognizable on the photographs - is the medio-lateral (or better the antero-lateral/postero-medial) flattening of the humerus shaft. This feature has long been considered as apomorphic for Neanderthal juveniles. However, comparison with both the Middle Palaeolithic immature humerus of Jebel Irhoud (a late archaic human from Morocco: Hublin et al. 1987; Hublin \& Tillier 1988) and young Chinese Homo erectus remains (Weidenreich 1941) leads to a new interpretation. Instead of being a Neanderthal apomorphy, it should be understood

left side state of maturation

$\begin{array}{ll}\text { location } & \begin{array}{l}\text { state of } \\ \text { maturation }\end{array} \\ \text { maxillary } & \begin{array}{l}\text { unerupted } \\ \text { in occlusion }\end{array} \\ \text { mandible } & \begin{array}{l}\text { in occlusion } \\ \text { unerupted }\end{array}\end{array}$

TABLE 2. State of maturation of the teeth. right side

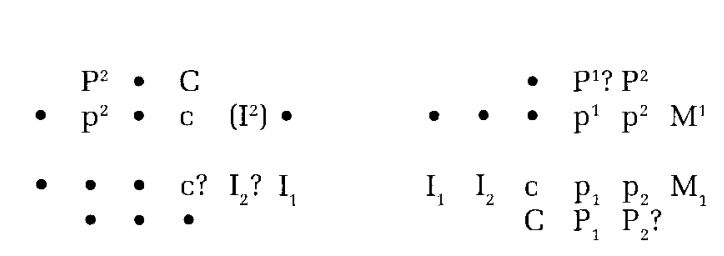

$x^{i}, x_{i}$ : deciduous teeth $\mathrm{X}^{\mathrm{i}}, \mathrm{X}_{\mathrm{i}}$ : permanent teeth - : missing or hidden teeth ( ): may be in occlusion 
as a plesiomorphy, encountered in archaic young Homo specimens: $H$. erectus, $H$. neanderthalensis and African late archaic humans (Hublin et al. 1987; Hublin \& Tillier 1988). Thus, the skeleton of Taramsa would be a rare example of an early anatomically modern child showing this feature.

Some approximate dimensions of the cranium in $\mathrm{mm}$, taken by two of us (CS \& WL) on a rapid inspection are as follows (with data on the somewhat more mature Qafzeh 11 child in square brackets for comparison): Glabello-occipital length 160.0 [163.0], Maximum (parietal) breadth $125 \cdot 0$ [131.0], Nasion-prosthion height 62.5 [56.0], Orbital breadth $39 \cdot 0$ [38.0], Orbital height $30 \cdot 0$ [30.0]. Those figures and their mutual combinations, including the relatively large face, could support the above-mentioned hypothesis concerning the systematic position of the Taramsa child.

\section{Conclusions}

This skeleton is important as it documents the Late Pleistocene human population of the Nile valley, about which little is known. There are no other skeletons attributed to the Middle or Upper Palaeolithic, except the skeletal material from Nazlet Khater (Thoma 1984; Vermeersch et al. 1984a; 1984b). The Taramsa skeleton is relevant to the issue of the origin of anatomically modern humans. It should be remembered that, in Western Europe, Neanderthals were still present around 32,000 years ago. For Africa, north of the equator, the burial of the Taramsa child is probably the oldest grave known so far. Even for Africa in general, there is only disputed evidence of burials older than this (e.g. Border Cave (Volman 1984)).

\section{References}

AITKEN, M.J. 1985. Thermoluminescence dating. New York (NY): Academic P'ress.

ANDERSON, J.E. 1968. Late Paleolithic skeletal remains from Nubia, in F. Wendorf (ed.), Prehistory of Nubia: 996-1040. Dallas (TX): Southern Methodist University Press.

Arambourc, C., M. Boule, H. Vallois \& R. Verneau. 1934. Les grottes paléolithiques des Beni-Segoual (Algérie). Paris: Masson.

BROTHWELL, D.R, 1972. Digging up bones. London: British Museum. ENNOUCHI, E. 1962a. Un Néandertalien: l'homme du Jebel Irhoud (Maroc), L'Anthropologie 66: 279-99.

1962b. Origine du Néandertalien d'Irhoud, Société des Sciences Naturelles et Physiques du Maroc, Bulletin 42: 24766.

FEREMBACH, D. 1962. La nécropole épipaléolithique de Taforalt (Maroc oriental), Etude des squelettes humains. Rabat: Edita-Casablanca.
The presence of modern humans in subSaharan Africa, from the onset of the Late Pleistocene, has been supported by some palaeontologists, advocating an African origin of anatomically modern humans: (Stringer \& Andrews 1988; Mellars \& Stringer 1989), although the 'Out of Africa' hypothesis has been challenged from the palaeontological standpoint (Smith et al. 1989; Wolpoff 1989; Thorne \& Wolpoff 1992). However, if an 'Out of Africa' origin for modern humans is advocated, the geographic passage-way may have very likely been through the Nile valley. Unfortunately, no human remains older than 35,000 were previously known. The discovery of the Taramsa burial, which can be dated to about 55,000 years ago, alters this situation dramatically. There is now a skeleton, geographically intermediate between southern Africa and the Levant. Future research will be necessary to obtain a direct dating of the skeleton itself and to evaluate its anthropological characteristics.

Acknowledgements. The 1994 campaign was made possible by grants from the Belgian National Fund and the 'Onderzoeksfonds K.U. Leuven'. CC's work on the photographs in 1994-96 was supported by a research grant from the National Bank of Belgium. A short inspection of the remains by CS and WL was organized thanks to a grant from the Leakey Foundation. The Royal Belgian Academy of Sciences provided travel funding. This paper presents research results of the Belgian programme on Interuniversity Poles of Attraction (IUAP 28) initiated by the Belgian State, Prime Minister's Office, Science Policy Programming. The scientific responsibility is assumed by its authors. The expedition owes a great deal of gratitude to Mr Hussein El Afiuni, chief inspector at Qena governorate. In the field the team received the competent and permanent assistance of Mr Hilleil Mahmoud, inspector at Dandara.We gratefully acknowledge the aid of Dra Shawn Bubel in revising the English text.

GREENE, D.L. \& G.J. ARMELAGOS. 1972. The Wadi Halja mesolithic population. Amherst (MA): Amherst University.

Hublin, J.J. \& A.M. Tillier. 1988. Les enfants moustériens de Jebel Irhoud. Comparaison avec les Néandertaliens juvéniles d'Europe, Bulletins et Mémoires de la Société d'Anthropologie de Paris 5-xiv: 237-46.

1981. The juvenile mandible from Irhoud (Morocco): A phylogenetic interpretation, in C.B. Stringer (ed.), Aspects of human evolution: 167-85. London: Taylor \& Francis.

Hublin, J.J., A.M. Tillier \& J. Texier. 1987. L'humerus d'enfant moustérien (Homo 4) du Jebel Irhoud (Maroc) dans son contexte archeologique, Bulletins et Mémoires de la Société d'Anthropologie de Paris 4-xiv: 115-42.

HunTLEY, D.J., D.I. GodfreY-SMiTh \& M.L.W. TheWALT. 1985. Optical dating of sediments, Nature 313: 105-7.

Lecoux, P. 1966. Détermination de l'âge dentaire de quelques fossiles de la lignée humaine. Paris: Vigot. 
MCCown, T.D. \& A. KEITH. 1939. The Stone Age of Mount Carmel. Oxford.

MARKS, A.E. (ed.) 1976-83. Prehistory and paleoenvironments in the Central Negev, Israel. Dallas (TX): Southern Methodist University, Department of Anthropology, Institute for the study of earth and man.

Mellars, P.A. \& C.B. StRinger (ed.). 1989. The human revolution, behavioural and biological perspectives on the origins of modern humans. Edinburgh: Edinburgh University Press.

Smith, B.W., M.J. AITKEN, E.J. Rhodes, P.D. Robinson \& D.M. GELDARD. 1986. Optical dating: methodological aspects, Radiation Protection Dosimetry 17: 229- 233.

SMith, B.W., E. J. Rhodes, S. STOKES \& N.A. SPOONER. 1991. Optical dating of quartz, Radiation Protection Dosimetry 34: 75-8

SMTTH, B.H. 1991. Dental anthropology. New York (NY): Wiley, Liss.

SMTTH, F.H., A.B. FALSETTI \& S.M. DONELLY. 1989. Modern human origins, Yearbook of Physical Anthropology 32: 35-68.

STOKES, S. 1994. Optical dating of selected aeolian sediments from the Southwestern United States. Unpublished D.Phil thesis, Oxford University.

1993. Optical dating of sediment samples from Bir Tarwafi and Bir Sahara East: an initial report, in F. Wendorf, R. Schild, A.E. Close \& associates (ed.), Egypt during the Last Interglacial: 229-33. New York (NY): Plenum Press.

STRINGER, C.B. \& P. ANDREWS. 1988. Genetic and fossil evidence for the origin of modern humans, Science 239: 1263-8.

THOMA, A. 1984. Morphology and affinities of the Nazlet Khater Man, Journal of Human Evolution 13: 287-96.

THORNE, A. \& M.H. WOLPOFr. 1992. The multiregional evolution of humans, Scientific American 266: 76-83.

TILLier, A.M. 1984. L'enfant Homo 11 de Qafzeh (Israel) et son apport à la compréhension des modalites de croissance des squelettes mousteriens, Paléorient 10: 7-48.

UBELAKER, D.H. 1978. Human skeletal remains: excavation. analysis, interpretation. Chicago (IL): Aldine.

VALLoIS, H.V. \& T. ROCHE. 1958. La mandibule acheuléenne de Témara, Maroc, Comptes Rendues de l'Académie des Sciences 246(3), 113-16.
VALLOIS, H.V. 1951. Les restes humains de Dar-es-Soltan, in A. Ruhlmann (ed.), La grotte préhistorique de Dar-esSoltan, Institut des Hautes Études Marocaines 11: 179202.

VAN PEer, P. In press. The Nile Corridor and the Out-of-Africa model. An examination of the archaeological record, Current Anthropology: 39.

VAN PeER, P. \& P.M. Vermeersch. 1990. Middle to Upper Palaeolithic transition: the evidence for the Nile Valley, in P. Mellars (ed.), The emergence of modern humans an archaeological perspective: 139-59. Edinburgh: Edinburgh University Press.

VANDERMEERSCH, B. 1981. Les hommes fossiles de Qafzeh (Israël), Paris: CNRS.

VERMEERSCH, P.M. (ed.) In press. Palaeolithic mining sites in Middle and Upper Egypt. Leuven: Leuven University Press.

Vermeersch, P.M. \& E. Paulissen. 1997. Extensive Middle Paleolithic chert extraction in the Qena Area (Egypt), in R. Schild \& Z. Sulgostowska (ed.), Man and flint: 13342. Warsaw: Institute of Archaeology and Ethnology, Polish Academy of Sciences.

VermeERsch, P.M., E. PAULISSEN \& P. VAN PEer. 1995. Palaeolithic chert mining in Egypt, Archaeologica Polonia 33: 1130 .

VERMEeRsch, P.M., E. PAUlissen, G. Gitselings, M. OTTE, A. Thoma, P. VAn Peer \& R. Lauwers. 1984a. 33,000 year old mining site and related Homo in the Egyptian Nile Valley, Nature 309: 342-4.

Vermeersch, P.M., E. Paulissen, G. Gijselings, M. OtTe, A. THOMA \& C. CHARLIER. 1984b. Une minière de silex et un squelette du paléolithique supérieur ancien à Nazlet Khater, Haute Egypte, LAnthropologie 88: 231-44.

VOLMAN, T.P. 1984. Early Prehistory of southern Africa, in R.G. Klein (ed.), Southern Africa prehistory and palaeoenvironment: 169-220. Rotterdam: Balkema.

WEIDENREIC, , F. 1941. The extremity bones of Sinanthropus pekinensis, Palaeontologia Sinica (new series) D-5. Peking.

WolpofF, M.H, 1989. The fossil alternative to Eden, in Mellars \& Stringer (ed.): 62-108. 